\title{
Utilization of Information Technology as Media for Village Community Aspirations
}

\author{
Dedy Arisandi ${ }^{1 *}$, Maya Silvi Lydia ${ }^{1}$, Seniman ${ }^{1}$, Indra Aulia ${ }^{1}$ \\ ${ }^{1}$ Faculty of Computer Science and Information Technology, Universitas Sumatera Utara, \\ Medan, Indonesia \\ *Email: dedyarisandi@usu.ac.id
}

\begin{abstract}
The ease and openness of information is a necessity that demanded by society. Easy and fast access to information utilizing advances in information and communication technology can actually improve services to the community. Badan Permusyawaratan Desa (BPD) Saentis dan Kolam Kecamatan Percut Sei Tuan for the embodiment of democracy in the implementation of the village government are expected to be able to optimally provide information services to the village community. Until now, information service activities have not utilized online media that can be accessed easily and quickly to explore, accommodate, and channel the aspirations of the village community. Therefore, we need a system in the form of an application that can be used by BPD to explore, collect, and channel the aspirations of village communities online. The method applied in developing this application is the User Centered Design method, which is a user-focused design. The next, the target achieved is the availability of a web-based media for channeling the aspirations of rural communities that can be used easily and quickly.
\end{abstract}

\section{Keyword: Online Aspirations, User Centered Design, Badan Permusyawaratan Desa}

\begin{abstract}
Abstrak
Kemudahan dan keterbukaan informasi saat ini merupakan kebutuhan yang menjadi tuntuan masyarakat. Akses informasi yang mudah dan cepat memanfaatkan kemajuan teknologi informasi dan komunikasi ternyata dapat meningkatkan pelayanan kepada masyarakat. Badan Permusyawaratan Desa (BPD) Saentis dan Kolam Kecamatan Percut Sei Tuan sebagai lembaga perwujudan demokrasi dalam penyelenggaraan pemerintah desa diharapkan mampu secara optimal memberikan pelayanan informasi kepada masyarakat desa. Aktivitas pelayanan informasi sampai saat ini belum memanfaatkan media online yang dapat diakses dengan mudah dan cepat untuk menggali, menampung, dan menyalurkan aspirasi masyarakat desa. Oleh karena itu dibutuhkan suatu sistem dalam bentuk aplikasi yang dapat digunakan oleh BPD untuk menggali, mengumpulkan, dan menyalurkan aspirasi masyarakat desa secara online. Metode yang diterapkan dalam pengembangan aplikasi ini adalah metode User Centered Design yaitu perancangan yang berfokus pada pengguna. Selanjutnya target yang dicapai adalah tersedianya media penyaluran aspirasi masyarakat desa berbasis web yang dapat digunakan dengan mudah dan cepat.
\end{abstract}

Kata Kunci: Aspirasi Online, User Centered Design, Badan Permusyawaratan Desa

\section{PENDAHULUAN}

Dalam UU No 6 tahun 2014 tentang Desa disebutkan Desa adalah kesatuan masyarakat hukum yang memiliki batas wilayah yang berwenang untuk mengatur dan mengurus urusan pemerintahan, kepentingan masyarakat setempat berdasarkan prakarsa masyarakat, hak asal usul, dan/atau hak tradisional yang diakui dan dihormati dalam sistem pemerintahan Negara Kesatuan Republik Indonesia. Desa memiliki pemerintahan sendiri. Pemerintahan Desa terdiri atas Pemerintah Desa (yang meliputi Kepala Desa dan Perangkat Desa) dan Badan Permusyawaratan Desa (BPD). Badan Permusyawaratan 
Desa merupakan lembaga perwujudan demokrasi dalam penyelenggaraan pemerintahan desa. BPD merupakan lembaga baru di desa pada era otonomi daerah di Indonesia.

BPD memiliki wewenang untuk membahas rancangan peraturan desa bersama Kepala Desa, melaksanakan pengawasan terhadap pelaksanaan Peraturan Desa dan Peraturan Kepala Desa, Mengusulkan pengangkatan dan pemberhentian Kepala Desa, membentuk panitia pemilihan Kepala Desa, menggali, menampung, menghimpun, merumuskan dan menyalurkan aspirasi masyarakat desa. Selain memilik wewengan, BPD Desa Saentis dan BPD Desa Kolam Kecamatan Percut Sei Tuan, Kabupaten Deli Serdang juga mempunyai hak meminta keterangan kepada Pemerintah Desa dan menyatakan pendapat untuk kemajuan desa.

BPD sebagai lembaga yang mewakili masyarakat untuk menyampaikan aspirasi mereka langsung kepada Pemerintah Desa. Kegiatan ini mendistribusikan, menyalurkan ide dan harapan untuk meningkatkan kualitas hidup dan mensejahterakan masyarakat desa (Andri et al., 2018). Aspirasi masyarakat ini sebenarnya sangat banyak dan beraneka ragam untuk kemajuan desanya, hanya saja mereka tidak memiliki ruang yang cukup untuk menyampaikannya. Oleh karena itu dibutuhkan sebuah sistem yang dapat digunakan untuk menghimpun, mengumpulkan dan menyalurkan aspirasi masyarakat ini. Setiap aspirasi masyarakat harus dengan mudah disampaikan, disalurkan dan diakses oleh setiap orang yang membutuhkannya. Situasi ini sebenarnya dapat diatasi dengan mengembangkan suatu sistem online yang dapat mengumpulkan dan menyalurkan aspirasi masyarakat dengan mudah.

Masyarakat dapat menyalurkan aspirasi mereka secara langsung tanpa harus bertemu dengan Pemerintah Desa atau dengan Badan Permusyawaratan Desa. Setiap aspirasi yang disampaikan dapat ditanggapi secara langsung oleh BPD dan masyarakat tersebut dapat pula melihat status aspirasinya dari awal disampaikan sampai tanggapan akhir dari pihak terkait tentang aspirasi tersebut. Masyarakat Desa juga dapat melihat langsung informasi tentang perkembangan desanya, informasi yang up to date, dan informasi dalam bentuk lainnya seperti pengumuman, berita, peraturan dan agenda kegiatan desanya.

\section{METODE PELAKSANAAN}

Metode pendekatan yang digunakan adalah dengan pendekatan User Centered Design (UCD). Konsep dari UCD adalah user sebagai pusat dari proses pengembangan sistem aspirasi masyarakat desa, dan tujuan/sifat-sifat, konteks dan lingkungan sistem semua didasarkan dari pengalaman pengguna (Amborowati, 2012). Pendekatan ini dilakukan untuk memfasilitasi pengguna sistem untuk dapat menerapkan apa yang mereka inginkan. Aktivitas yang dilakukan meliputi analisis kebutuhan aplikasi, pengembangan aplikasi, pemberian pelatihan kepada seluruh elemen desa.

Dalam rangka melaksanakan pengabdian kepada masyarakat, terdapat tahapan-tahapan yang dilakukan sebagaimana yang disajikan pada Gambar 2.1. 


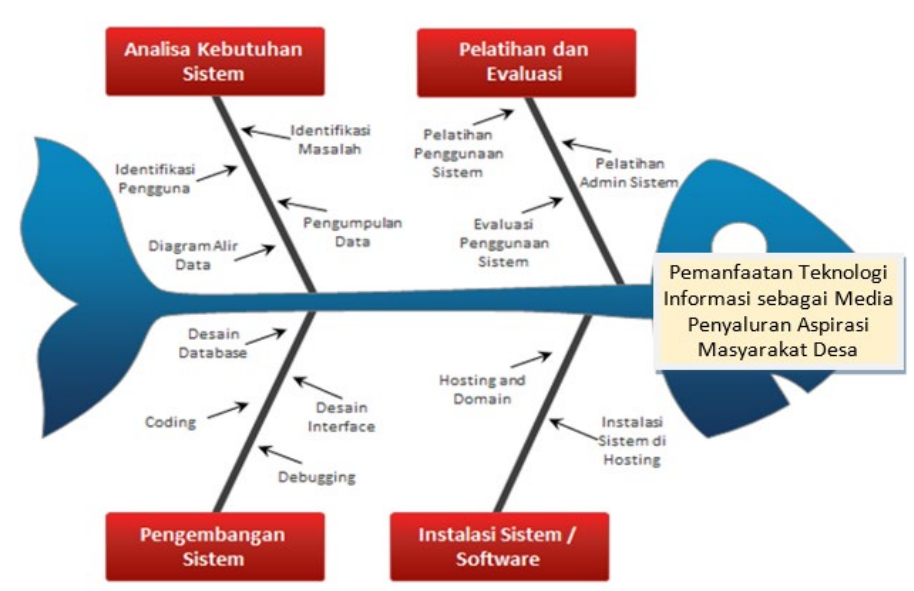

Gambar 2.1. Diagram Fishbone Tahapan Pengabdian kepada Masyarakat

Berdasarkan Gambar 2.1, pengabdian kepada masyarakat yang dilakukan terdiri atas 4 (empat) tahapan kerja. Tahapan kerja yang dimaksud adalah sebagai berikut:

\subsection{Analisa Kebutuhan Sistem}

Tahap ini merupakan tahap kerja awal yang dilaksanakan oleh tim pengabdian. Tim akan melakukan analisa kebutuhan untuk pengembangan sistem dengan cara mengidentifikasi masalah dan pengguna yang nantinya akan mendukung pengembangan sistem. Pada tahap ini, tim juga akan mengumpulkan data yang berguna untuk mengembangkan modul-modul yang diimplementasikan ke dalam sistem.

Dalam membantu menganalisis sistem yang dibangun, tim pengabdian membuat use case diagram (UML) dan entity relationship diagram (ERD) dalam membantu membangun database sistem.

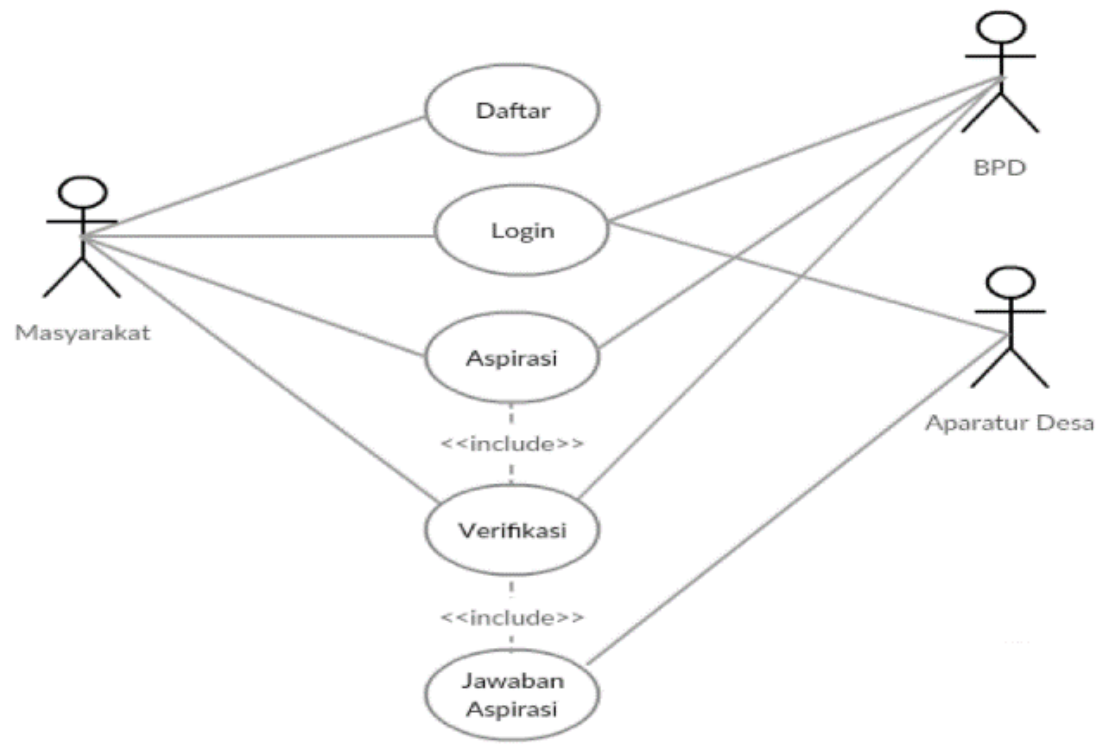

Gambar 2.2. Use Case Diagram Aplikasi Aspirasi Online 


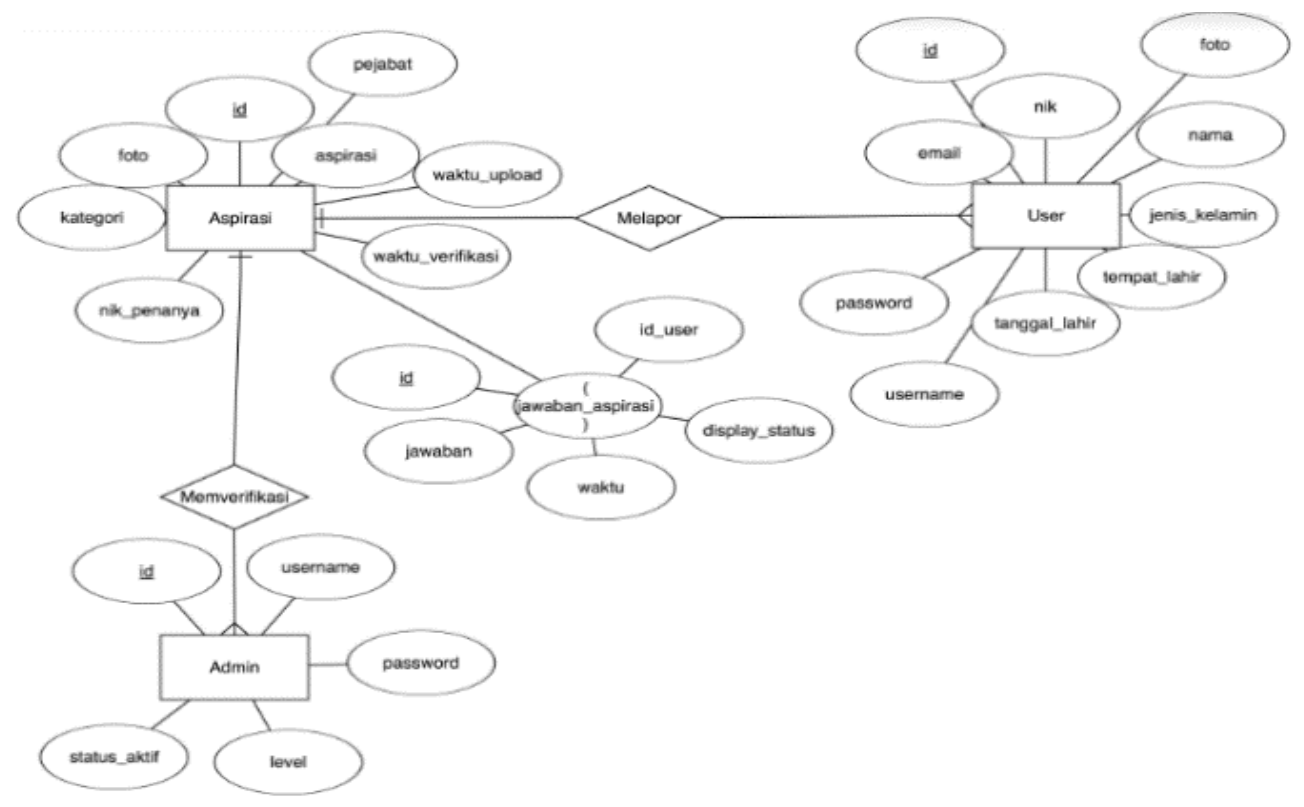

Gambar 2.3. Entity Relationship Diagram Aplikasi Aspirasi Online

\subsection{Pengembangan Aplikasi}

Teknologi Informasi dan Komunikasi memberikan pengaruh besar terhadap pembangunan pedesaan (Badri, 2016). Salah satu penerapan teknologi informasi adalah dengan pengembangan aplikasi untuk desa. Pengembangan aplikasi merupakan tahap kerja kedua dalam pengabdian kepada masyarakat dimana tim pengabdian akan melakukan pengembangan aplikasi yang memiliki fitur-fitur sesuai dengan solusi dari permasalahan yang telah dikumpulkan melalui analisa kebutuhan sistem. Berdasarkan pada hasil analisa, tim merancang desain basis data dan desain tampilan yang akan digunakan pada implementasi sistem. Setelah desain basis data dan tampilan diselesaikan, tim pengabdian akan melanjutkan pengembangan aplikasi ke dalam tahap coding. Setelah melakukan coding, tim akan melakukan proses terakhir pada tahap kerja kedua ini yaitu debugging. Debugging bertujuan untuk menemukan celah dan kesalahan serta memperbaiki kesalahan-kesalahan yang tampil baik secara sengaja ataupun tanpa sengaja (Jogiyanto, 2005).

\subsection{Instalasi Aplikasi}

Tahap kerja ketiga pada pengabdian kepada masyarakat adalah Instalasi Aplikasi. Pada tahapan kerja ini, tim pengabdian akan melakukan instalasi aplikasi untuk masing-masing desa mitra. Selain itu, tim pengabdian juga akan memberikan infrastruktur perangkat yang akan menunjang penggunaan sistem yang telah dioptimalkan kepada masing-masing desa mitra dimaksud. Selanjutnya, aplikasi yang telah selesai dikembangkan, akan diinstal di server dan komputer yang terdapat di Desa (client). Aplikasi yang akan dibangun nanti akan memiliki klasifikasi hak akses yang berbeda-beda untuk setiap account. Misalnya untuk masyarakat desa hanya dapat melihat informasi dan memasukkan aspirasi saja, berbeda dengan Kepala Desa atau Ketua BPD.

\subsection{Pelatihan dan Evaluasi}

Tahap kerja akhir dari kegiatan pengabdian kepada masyarakat adalah Pelatihan dan Evaluasi. Pada tahap ini, tim mengadakan pelatihan kepada Ketua dan Anggota BPD dan setiap elemen desa. Selain itu 
pelatihan ini juga difokuskan pada masyarakat desa yang juga akan menggunakan sistem yang dibangun. Pada tahap ini akan dilakukan evaluasi sistem dan akan dilihat kinerja sistem apakah mudah dimengerti dan dapat digunakan serta dipahami dengan baik penggunaannya. Evaluasi juga dilakukan terkait dengan kinerja sistem berupa kecepatan, keamanan, integritas dan kredibilitas data untuk kenyamanan dalam mengakses sistem.

\section{HASIL DAN PEMBAHASAN}

Hasil yang diperoleh dalam penerapan pengembangan aplikasi keluhan masyarakat berbasis online yang dilaksanakan di Desa Saentis dan Desa Kolam Kecamatan Percut Sei Tuan Deli Serdang menunjukkan banyaknya keluhan yang dapat ditampung dan ditanggapi sejak dini sebelum meluas. Aparatur Desa dapat terbantu dalam memajukan daerahnya dengan bantuan masyarakat yang melaporkan adanya permasalahan di sekitar lingkungan mereka sehingga proses kontrol terhadap permasalahan dapat lebih ditingkatkan.

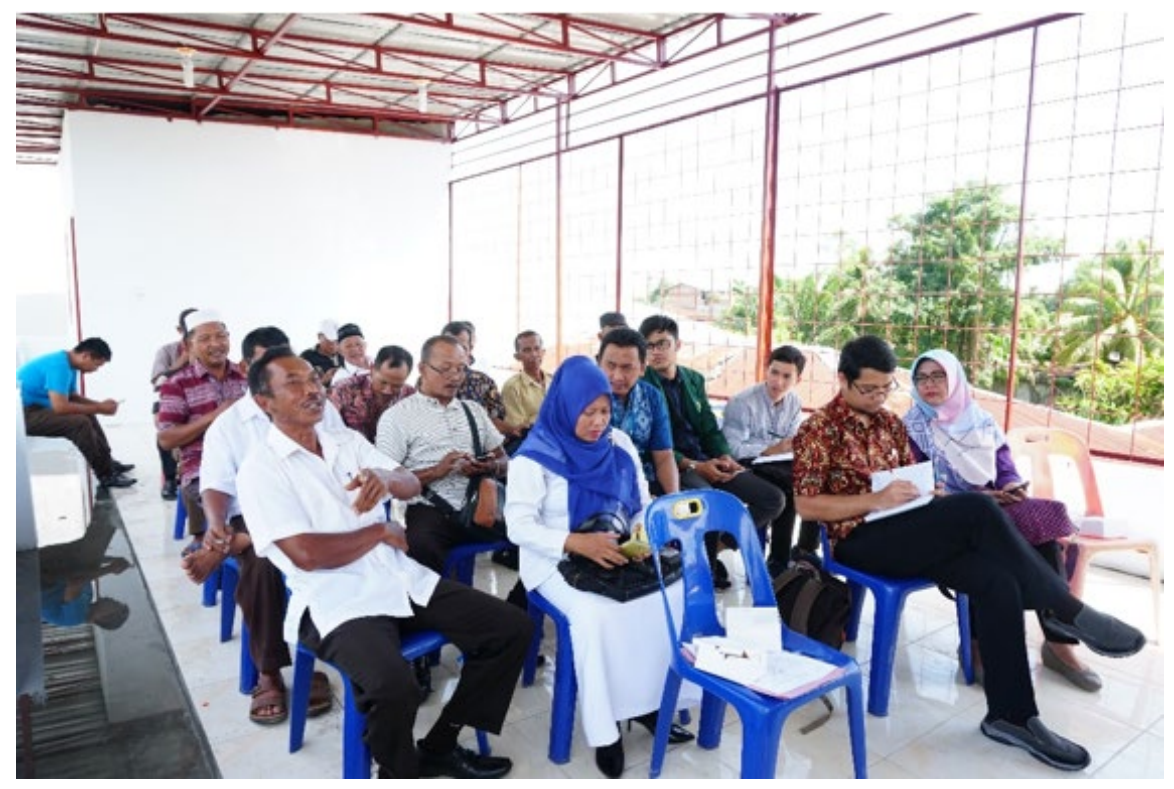

Gambar 3.1. Pelasanaan Pengabdian kepada Masyarakat Penerapan Aspirasi Online

Aplikasi aspirasi masyarakat online dapat digunakan oleh masyarakat desa dan dapat dikelola dengan baik oleh Badan Permusyawatan Desa. Tampilan aplikasi disisi masyarakat berbeda dengan tampilan disisi pengelola aplikasi. Tampilan beranda memperkenalkan tentang desa, profil, visi misi, berita dan galeri dapat dilihat pada gambar 3.2. 


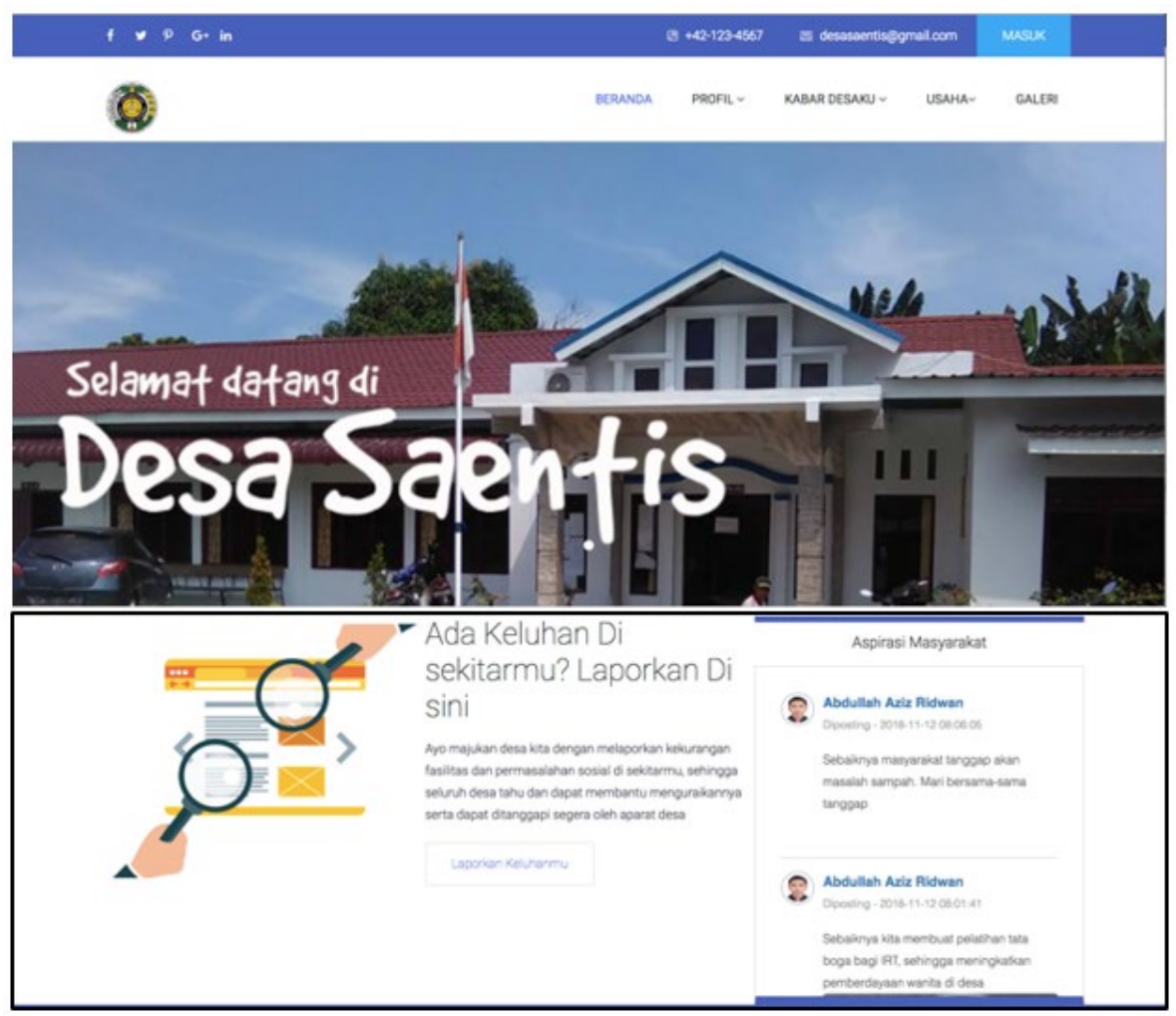

Gambar 3.2. Tampilan Utama Aplikasi Aspirasi Online

Masyarakat yang akan menggunakan aplikasi ini harus melakukan registaris terlebih dahulu. Registrasi dan login sebagai masyarakat, aparatur desa, pengisi konten website desa dan BPD serta menghubungkan ke laman daftar sebagai pengguna baru.

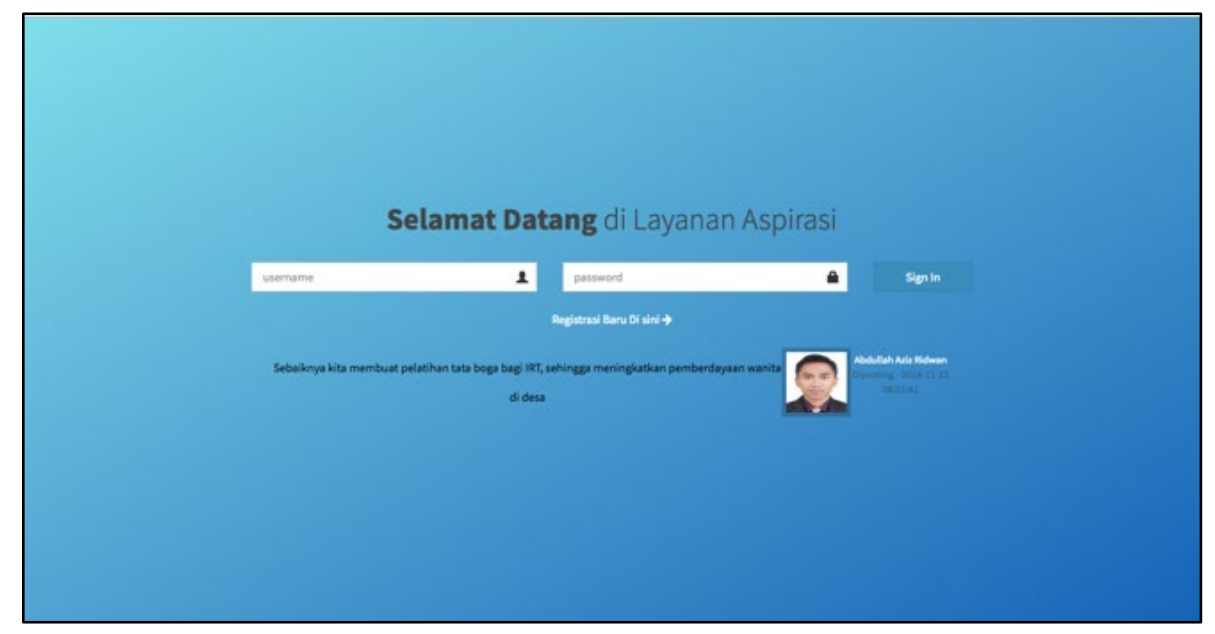

Gambar 3.3. Laman Login 
Setelah berhasil mendaftar, masyarakat akan dikirimkan kode verifikasi oleh sistem secara otomatis ke email calon pengguna aplikasi. Masyarakat wajib memasukkan kode verifikasi jika ingin akunnya terverifikasi dan dapat menggunakan aplikasi aspirasi online.

Selanjutnya masyarakat yang sudah memiliki hak akses diaplikasi dapat mengirimkan aspirasinya seperti yang ditampilkan pada gambar 3.4. Laman ini menampilkan aspirasi masyarakat, riwayat aspirasi yang telah dilaporkan dan pelaporan aspirasi di sisi kiri tampilan.

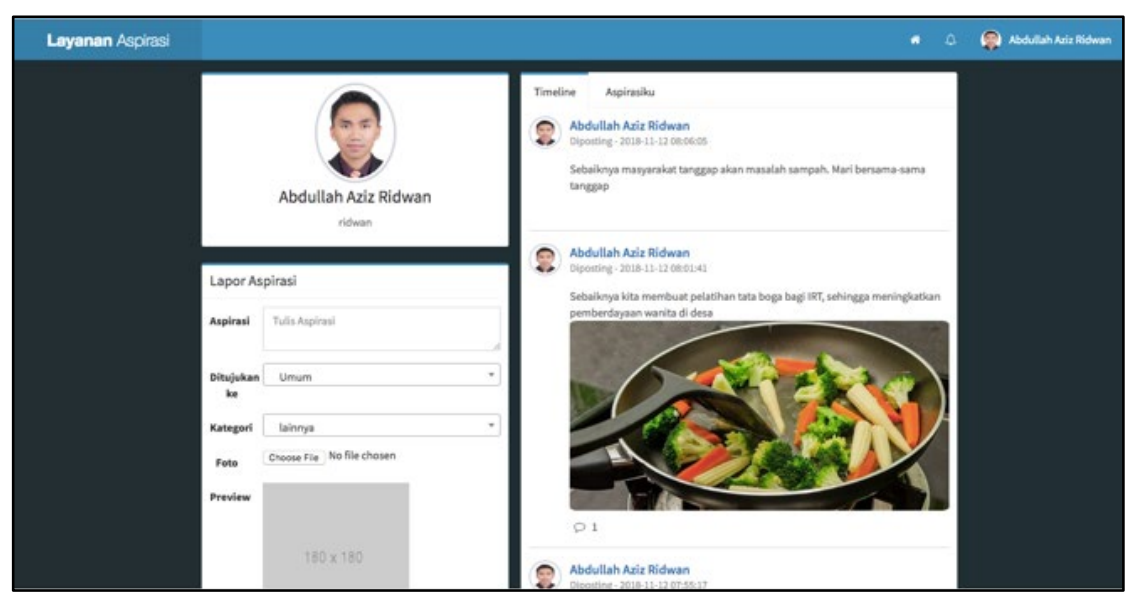

Gambar 3.4. Laman Keluhan Masyarakat

Aspirasi yang dikirim oleh masyarakat selanjutnya akan tersimpan pada database aplikasi. Aspirasi masyarakat tersebut harus diverifikasi oleh BPD. Verifikasi aspirasi dilakukan untuk memfilter apakah aspirasi layak ditampilkan kepada publik atau tidak. Selanjutnya pada gambar 3.5, aparatur desa dapat melihat aspirasi desa yang ditujukan kepada salah satu aparatur desa.

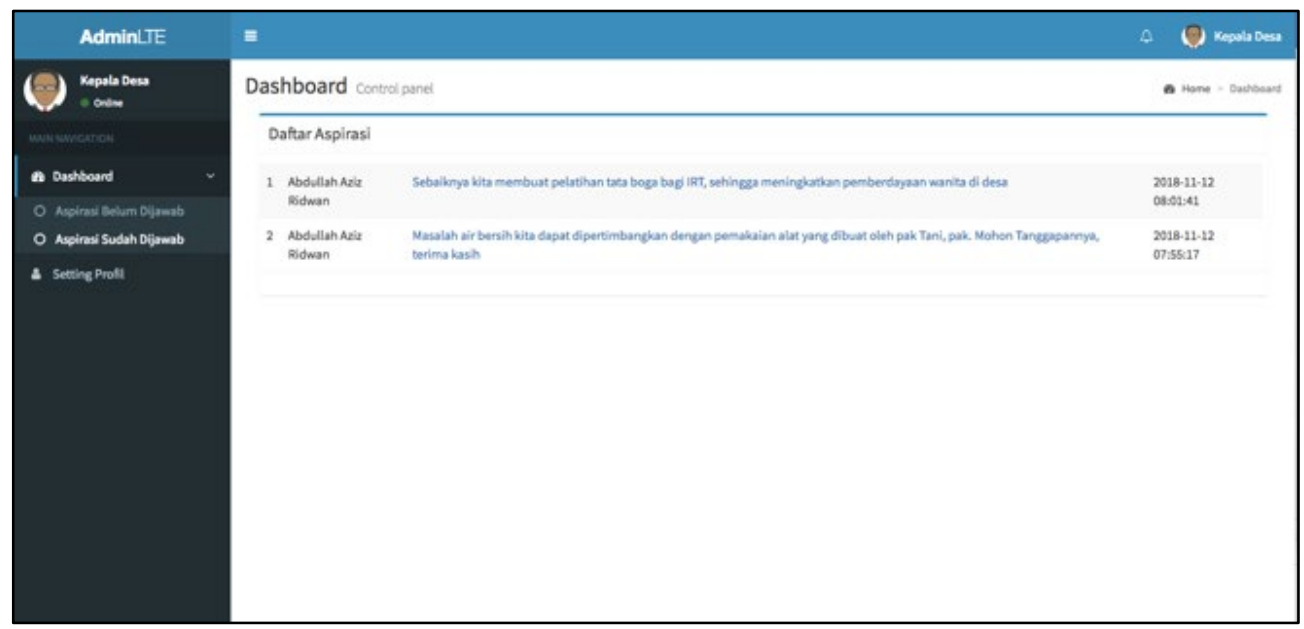

Gambar 3.5. Daftar Aspirasi Masyarakat pada Akun Aparatur Desa 


\section{KESIMPULAN}

Berdasarkan kegiatan pengabdian kepada masyarakat yang dilakukan dapat ditarik kesimpulan sebagai berikut:

1. Pengembangan aplikasi untuk penyaluran aspirasi masyarakat desa ini terbukti dapat diterapkan dengan baik sebagai strategi pengingkatan efisiensi pelayanan informasi pada desa mitra.

2. Selain aspirasi, masyarakat desa juga dapat melihat kemajuan desa, aktivitas desa, berita, pengumuman, dan prestasi desanya.

3. Dengan pengembangan aplikasi ini BPD, Aparatur Desa, dan Masyarakat Desa dapat bersamasama meningkatkan kemajuan desanya dan efisiensi waktu yang optimal dalam proses penyampaian aspirasi.

4. BDP memiliki pusat data yang setiap saat dapat digunakan oleh pihak-pihak terkait dalam pengambilan kebijakan dimasa mendatang.

5. Masyarakat Desa merasakan manfaat yang sangat besar dalam hal palayanan informasi yang mudah, cepat, dan up to date.

\section{UCAPAN TERIMAKASIH}

Kegiatan Pengabdian Kepada Masyarakat ini dapat teraksana berkat bantuan dana NON PNBP Universitas Sumatera Utara sesuai Kontrak Pelaksanaan Program Pengabdian Kepada Masyarakat Program Mono Tahun Tahun Anggaran 2018 dengan nomor kontrak 172/UN5.2.3.2.1/PPM/2018.

\section{DAFTAR PUSTAKA}

Amborowati, A. (2012). Rancangan Sistem Pameran Online menggunakan Metode UCD (User Centered Design). STMIK AMIKOM.

Andri, Ketut Gunawan, \& Budiman (2018). Studi Tentang Penyaluran Aspirasi Oleh Badan Permusyawaratan Desa (BPD) dalam Meningkatkan Pembangunan di Desa Senambah, Desa Ngayau, Desa Mulupan Kecamatan Muara Bengkal Kabupaten Kutai Timur. eJournal Ilmu Pemerintahan, Volume 6, Nomor 1. Universitas Mulawarman Samarinda.

Badri, Muhammad. (2016). Sistem Komunikasi Pembangunan Pedesaan Berbasis Teknologi Informasi dan Komunikasi. Prosiding Komunikasi. Universitas Lampung.

Jogiyanto. (2005). Analisis \& Desain Sistem Informasi: pendekatan terstruktur teori dan praktek aplikasi bisnis. Andi, Yogyakarta.

Undang-Undang Republik Indonesia Nomor 6 Tahun 2014 Tentang Desa. 